\title{
PENGARUH MOTIVASI DAN BUDAYA ORGANISASI TERHADAP KEPUASAN KERJA SERTA IMPLIKASINYA TERHADAP KINERJA KARYAWAN PADA RUMAH SAKIT UMUM (RSU) SALATIGA
}

\author{
Oleh \\ Mada Adi Wibowo \\ Dosen Tetap STIE AMA Salatiga \\ Yanuar Surya Putra \\ Dosen Tetap STIE AMA Salatiga
}

\begin{abstract}
Abstrak
Penelitian ini bertujuan untuk menguji pengaruh motivasi dan kompetensi terhadap kinerja pegawai. Di samping itu, penelitian ini juga bertujuan untuk menguji pengaruh variabel intervening kepuasan kerja pada hubungan antara motivasi dan budaya organisasi terhadap kinerja karyawan.

Populasi dalam penelitian ini adalah seluruh karyawan pada RSU (Rumah Sakit Umum) Salatiga, Jl.Osamaliki No.19 Salatiga yang berjumlah 621 karyawan. Sampel yang diambil sebanyak 86 karyawan. Teknik pengambilan sampel adalah teknik acak dengan simple random sampling. Jenis data yang digunakan primer dan sekunder. Metode pengumpulan datanya adalah kuesioner dan dokumentasi. Teknik analisis yang digunakan Analisis Jalur.

Hasil penelitian menunjukkan bahwa : 1). Motivasi berpengaruh signifikan terhadap kepuasan kerja $(t=4,110$ sig. 0,000 $<\alpha=0,05)$. 2). Budaya Organisasi berpengaruh signifikan terhadap kepuasan kerja $(t=4,850$ sig. $0,000<\alpha=0,05)$. 3). Kepuasan kerja berpengaruh signifikan terhadap kinerja karyawan $(t=5,454$ sig. $0,000<\alpha=0,05)$. 4). Motivasi berpengaruh signifikan terhadap kinerja karyawan ( $t$ $=2,103$ sig. 0,039 $<\alpha=0,05)$. 5). Budaya Organisasi berpengaruh signifikan terhadap kinerja karyawan $(t=2,445$ sig. 0,017 $<\alpha=0,05)$. 6). Kepuasan kerja menjadi variabel intervening antara motivasi terhadap kinerja karyawan $(0,209<$ 0,223). 7). Kepuasan kerja menjadi variabel intervening antara budaya organisasi terhadap kinerja karyawan $(0,250<0,260)$.
\end{abstract}

Kata Kunci : Motivasi, Budaya Organisasi, Kepuasan Kerja, Kinerja Karyawan

\section{PENDAHULUAN}

\section{Latar Belakang Masalah}

Keberhasilan suatu organisasi sangat dipengaruhi oleh kinerja individu karyawannya. Setiap organisasi atau perusahaan akan selalu berusaha untuk meningkatkan kinerja karyawan, dengan harapan apa yang menjadi tujuan perusahaan akan tercapai. Berbagai cara akan ditempuh oleh perusahaan dalam meningkatkan 
kinerja karyawannya, misalnya dengan melalui pendidikan, pelatihan, menciptakan lingkungan kerja yang kondusif dan sebagainya (Guritno dan Waridin,2005;63).

Kinerja karyawan adalah perilaku nyata yang ditampilkan setiap karyawan sebagai prestasi kerja yang dihasilkan sesuai dengan perannya dalam perusahaan (Rivai,2004:309). Pada setiap orang yang bekerja atau dalam suatu kelompok kerja, kinerja selalu diharapkan bisa senantiasa baik kualitas dan kuantitasnya. Untuk mendapatkan hasil itu sendiri haruslah didukung dengan penetapan tujuan dan diawali dengan perencanaan kerja yang rasional. Maksud penetapan tujuan kinerja adalah menyusun sasaran-sasaran yang berguna tidak hanya sebagai pedoman mencapai tujuan, tetapi juga bisa menjadi sarana evaluasi kinerja pada akhir periode dan untuk mengelola keadaan pasca kerja selama periode tersebut (Setiyawan dan Waridin,2006:184).

Salah satu faktor yang dapat mempengaruhi kinerja karyawan adalah kepuasan kerja. Kepuasan kerja merupakan merupakan sikap umum individu terhadap pekerjaannya atau penilaian karyawan atas seberapa puas atau tidak puas dirinya dengan pekerjaannya (Robbins,2006:103).). Kepuasan kerja merupakan masalah strategis, karena tidak terpenuhinya kepuasan kerja akan berdampak pada hasil kerja yang kurang maksimal, dengan kualitas rendah, target tidak terpenuhi dan akhirnya kepuasan konsumen akan berkurang. Apabila hal ini terjadi, maka perusahaan akan menghadapi masalah yang sangat serius yaitu dapat mengalami kebangkrutan.

Banyak sekali faktor-faktor yang dapat mempengaruhi kepuasan kerja. Dalam penelitian ini, faktor-faktor yang mempengaruhi kepuasan kerja dianalisis melalui motivasi dan budaya organisasi. Faktor pertama yang dapat mempengaruhi kepuasan kerja adalah motivasi. Motivasi merupakan proses mempengaruhi atau mendorong dari luar terhadap seseorang atau kelompok kerja agar mereka mau melaksanakan sesuatu yang telah ditetapkan (Samsudin, 2006:281). Motivasi mempunyai kekuatan kecenderungan seseorang/individu untuk melibatkan diri dalam kegiatan yang mengarah kepada sasaran dalam pekerjaan sebagai kepuasan, tetapi lebih lanjut merupakan perasaan senang atau rela bekerja untuk mencapai tujuan pekerjaan. Motivasi sebagai suatu reaksi yang diawali dengan adanya kebutuhan yang menumbuhkan keinginan atau upaya mencapai tujuan yang selanjutnya menimbulkan ketegangan yaitu keinginan yang belum terpenuhi, yang kemudian menyebabkan 
timbulnya tindakan yang mengarah kepada tujuan dan akhirnya akan memuaskan keinginan

Faktor kedua adalah budaya organisasi. Budaya organisasi adalah satu wujud anggapan yang dimiliki, diterima secara implisit oleh kelompok dan menentukan bagaimana kelompok tersebut merasakan, memikirkan, dan bereaksi terhadap lingkungannya yang beraneka ragam (Kreitner dan Kinicki,2003:79). Dalam setiap organisasi, budaya kerja selalu diharapkan baik karena baiknya budaya kerja akan berhubungan dengan berhasil atau tidaknya tujuan organisasi dicapai. Dengan budaya organisasi yang baik, biasanya organisasi akan mudah mengatasi masalah yang dihadapi dan bisa mencapai tujuan organisasi dengan mengandalkan kekuatan yang ada di organisasi (Setiyawan dan Waridin,2006: 190). Adanya budaya organisasi yang baik, biasanya dapat mempengaruhi kinerja karyawannya.

Pengaruh antara Motivasi dan Budaya Organisasi terhadap Kinerja telah dilakukan penelitian oleh beberapa peneliti sebelumnya yang menunjukkan hasil yang berbeda (gap research). Hasil penelitian Suharto dan Cahyono (2005) menyatakan bahwa Motivasi dan Budaya Organisasi berpengaruh terhadap Kinerja. Namun hasil penelitian Guritno dan Waridin (2005) menyatakan bahwa Motivasi tidak berpengaruh terhadap Kinerja serta Masrukin dan Waridin (2006) menyatakan bahwa Budaya Organisasi tidak berpengaruh terhadap Kinerja. Hasil ini menunjukkan bahwa telah terjadi kesenjangan (gap research) antara dua temuan dari dua penelitian tersebut.

RSU Salatiga, adalah salah satu Rumah Sakit Negeri di Salatiga. Ketatnya persaingan di dunia pelayanan kesehatan, membuat RSU Salatiga, selalu berusaha mengadopsi perubahan-perubahan dan perkembangan-perkembangan baik dari segi teknologi maupun tenaga kerja atau sumber daya manusia. Selain itu, kualitas pelayanan kepada pasien juga terus ditingkatkan. Dari segi teknologi, RSU Salatiga, berusaha mengadopsi teknologi terbaru untuk diterapkan, sehingga hal tersebut dapat memudahkan pelayana kesehatan kepada pasien baik rawat inap maupun rawat jalan. Hal ini merupakan poin tersendiri bagi RSU Salatiga, juga menawarkan pelayananpelayanan spesialis seperti unit stroke, klinik mata, klinik bedah dan lain-lain serta variasi layanan yang ada untuk meningkatkan layanan yang prima. Karyawan dituntut proaktif dalam meningkatkan pelayanan. 
Berdasarkan uraian tersebut, maka judul yang diambil adalah "PENGARUH MOTIVASI DAN BUDAYA ORGANISASI TERHADAP KEPUASAN KERJA SERTA IMPLIKASINYA TERHADAP KINERJA KARYAWAN PADA RUMAH SAKIT UMUM (RSU) SALATIGA"

\section{Rumusan Masalah}

Berdasarkan latar belakang yang telah diuraikan, maka pertanyaan penelitian ini adalah :

1. Apakah motivasi berpengaruh terhadap kepuasan kerja karyawan RSU Salatiga ?

2. Apakah budaya organisasi berpengaruh terhadap kepuasan kerja karyawan RSU Salatiga?

3. Apakah kepuasan kerja berpengaruh terhadap kinerja karyawan RSU Salatiga?

4. Apakah motivasi berpengaruh terhadap kinerja karyawan RSU Salatiga?

5. Apakah budaya organisasi berpengaruh terhadap kinerja karyawan RSU Salatiga?

\section{Tujuan dan Manfaat Penelitian}

Tujuan penelitian:

Berdasarkan perumusan masalah yang telah dikemukakan, maka tujuan penelitian ini adalah :

1. Untuk menganalisis pengaruh motivasi terhadap kepuasan kerja karyawan RSU Salatiga.

2. Untuk menganalisis pengaruh budaya organissai terhadap kepuasan kerja karyawan RSU Salatiga.

3. Untuk menganalisis pengaruh kepuasan kerja terhadap kinerja karyawan RSU Salatiga.

4. Untuk menganalisis pengaruh motivasi terhadap kinerja karyawan RSU Salatiga.

5. Untuk menganalisis pengaruh budaya organisasi terhadap kinerja karyawan RSU Salatiga. 
Manfaat penelitian

1. Kegunaan Akademis

a. Pembaca

Penelitian ini diharapkan sebagai bahan informasi untuk menambah ilmu ilmu tentang manajemen sumber daya manusia.

b. Peneliti lebih lanjut

Penelitian ini merupakan bahan referensi bagi peneliti lain yang akan meneliti tentang variabel-variabel lain yang dapat mempengaruhi kinerja di RSU Salatiga.

c. Peneliti

Hasil penelitian ini diharapkan dapat memberikan sumbangan dalam pengembangan ilmu manajemen sumber daya manusia

2. Kegunaan Praktis

a. Penelitian ini diharapkan dapat memberikan sumbangan berupa informasi mengenai pentingnya kinerja karyawan RSU Salatiga

b. Penelitian ini dapat menambah pengetahuan bagi perusahaan mengenai faktorfaktor yang mempengaruhi kinerja karyawan, khususnya tentang kepemimpinan dan motivasi pada RSU Salatiga

\section{LANDASAN TEORI}

\section{Motivasi}

Motivasi adalah proses yang berperan pada intensitas arah, dan lamanya berlangsung individu ke arah pencapaian sasaran (Robbins,2006: 214). Definisi lain motivasi adalah proses mempengaruhi atau mendorong dari luar terhadap seseorang atau kelompok kerja agar mereka mau melaksanakan sesuatu yang telah ditetapkan (Samsudin,2006:281). Menurut Slamet (2007:125), motivasi adalah proses psikologis yang mendasar dan merupakan salah satu unsur yang dapat menjelaskan perilaku seseorang. Sedangkan menurut Hasibuan (2007:143), motivsi adalah pemberian daya penggerak yang dapat menciptakan kegairahan kerja seseorang ahar mereka mau bekerja sama, bekerja efektif dan terintegrasi dengan segala daya upayanya untuk mencapai kepuasan. 


\section{Budaya Organisasi}

Budaya organisasi adalah sistem makna bersama yang dianut oleh anggotaanggota yang membedakan organisasi itu dari organisasi-organisasi lain (Robbins,2006:721). Menurut Tampubolon (2004:178), budaya organisasi merupakan kumpulan persepsi secara umum dari seluruh karyawan sebagai anggota organisasi.

\section{Kepuasan Kerja}

Kepuasan kerja merupakan sikap umum individu terhadap pekerjaannya atau penilaian karyawan atas seberapa puas atau tidak puas dirinya dengan pekerjaannya (Robbins,2006:103). Definisi lain kepuasan kerja merupakan suatu sikap yang positif yang menyangkut penyesuaian diri yang sehat dari para karyawan terhadap kondisi dan situasi kerja, termasuk di dalamnya masalah upah, kondisi sosial, kondisi fisik, dan kondisi psikologis (Anoraga,2006:82). Sedangkan menurut Rivai (2004:475), kepuasan kerja merupakan evaluasi yang menggambarkan seseorang atas perasaan sikapnya senang atau tidak senang, puas atau tidak puas dalam bekerja.

\section{Kinerja Karyawan}

Kinerja karyawan adalah perilaku nyata yang ditampilkan setiap karyawan sebagai prestasi kerja yang dihasilkan sesuai dengan perannya dalam perusahaan (Rivai,2004:309). Menurut Simamora (2004:338), kinerja adalah hasil kerja karyawan terhadap kontribusinya kepada organisasi selama periode waktu tertentu. Menurut Sutrisno (2010:151), kinerja adalah hasil kerja yang telah dicapai seseorang dari tingkah laku kerjanya dalam melaksanakan aktivitas kerja. Sedangkan menurut Mangkunegara (2009:67), kinerja adalah hasil kerja secara kualitas dan kuantitas yang dicapai oleh seseorang pegawai dalam melaksanakan tugasnya sesuai dengan tanggungjawab yang diberikan kepadanya. 
Kerangka Pemikiran

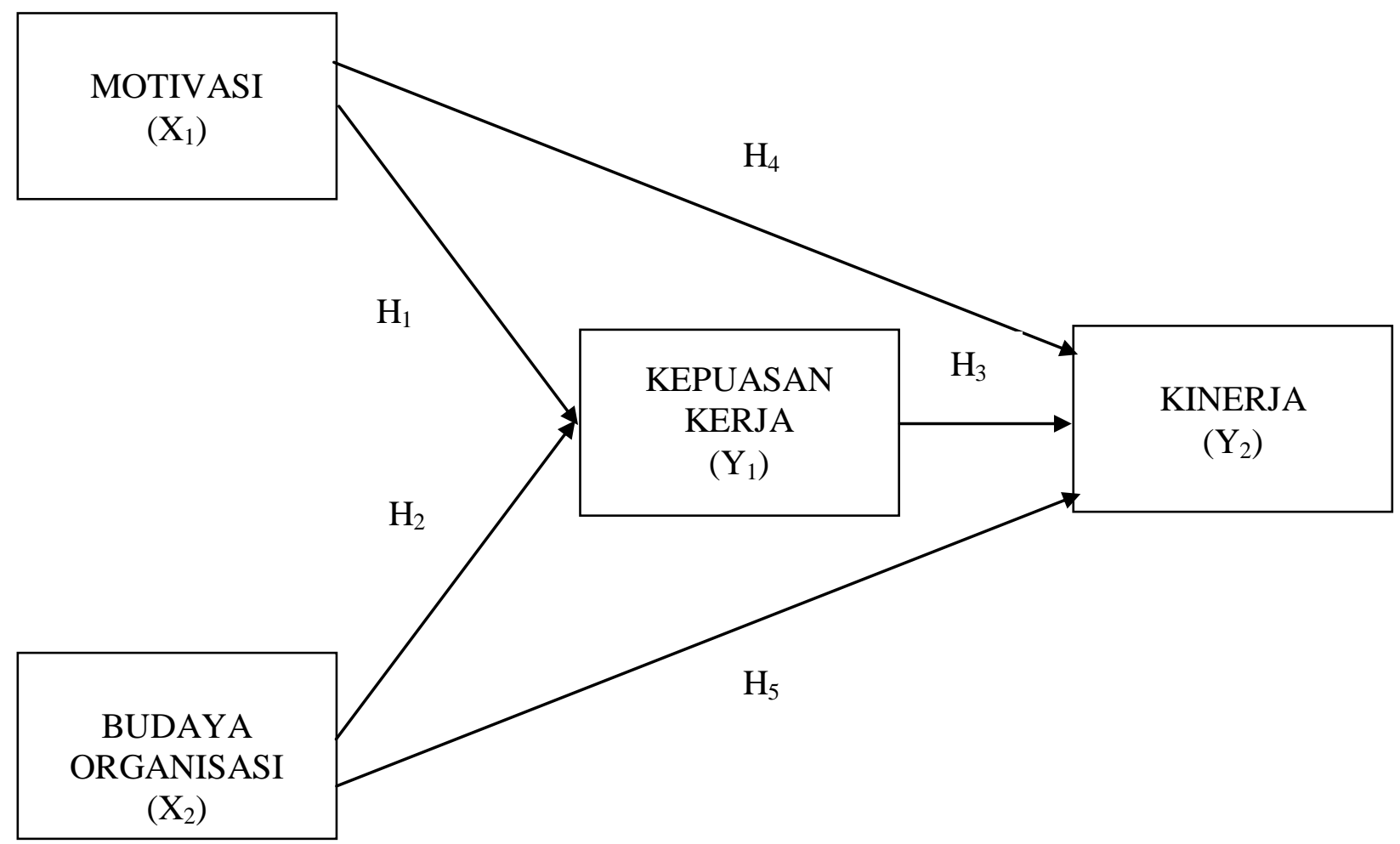

Gambar 1

Kerangka Pemikiran

\section{Hipotesis}

$\mathrm{H}_{1} \quad$ : Motivasi berpengaruh terhadap kepuasan kerja

$\mathrm{H}_{2}$ : Budaya organisasi berpengaruh terhadap kepuasan kerja

$\mathrm{H}_{3} \quad$ : Kepuasan kerja berpengaruh terhadap kinerja.

$\mathrm{H}_{4} \quad$ : Motivasi berpengaruh terhadap kinerja.

$\mathrm{H}_{5}$ : Budaya organisasi berpengaruh terhadap kinerja.

\section{Metode Penelitian}

1. Uji Instrumen : Uji Validitas dan Reliabilitas

2. Uji Kelayakan Model : Koefisien Determinasi (Adjusted R2) \& Uji - F

3. Analisis Jalur (Path Analysis)

4. Pengujian Hipotesis $(\mathrm{Uji}-\mathrm{t})$

5. Pengujian Variabel Intervening (Pengaruh Langsung dan Tidak Langsung) 


\section{Hasil Analisis Data}

Hasil Uji Validitas

\begin{tabular}{|c|c|c|c|}
\hline Variabel & Nilai Korelasi & Sig. & Keterangan \\
\hline Motivasi & & & \\
\hline Butir Pertanyaan 1 & 0,889 & $0,000<0,05$ & Valid \\
\hline Butir Pertanyaan 2 & 0,865 & $0,000<0,05$ & Valid \\
\hline Butir Pertanyaan 3 & 0,809 & $0,000<0,05$ & Valid \\
\hline Butir Pertanyaan 4 & 0,845 & $0,000<0,05$ & Valid \\
\hline Budaya Organisasi & & & \\
\hline Butir Pertanyaan 1 & 0,783 & $0,000<0,05$ & Valid \\
\hline Butir Pertanyaan 2 & 0,754 & $0,000<0,05$ & Valid \\
\hline Butir Pertanyaan 3 & 0,815 & $0,000<0,05$ & Valid \\
\hline Butir Pertanyaan 4 & 0,775 & $0,000<0,05$ & Valid \\
\hline Kepuasan Kerja & & & \\
\hline Butir Pertanyaan 1 & 0,780 & $0,000<0,05$ & Valid \\
\hline Butir Pertanyaan 2 & 0,843 & $0,000<0,05$ & Valid \\
\hline Butir Pertanyaan 3 & 0,734 & $0,000<0,05$ & Valid \\
\hline Butir Pertanyaan 4 & 0,820 & $0,000<0,05$ & Valid \\
\hline Sumber : Data Primer Dion
\end{tabular}

Sumber : Data Primer Diolah (2015)

Hasil Uji Validitas

\begin{tabular}{|c|c|c|c|}
\hline Kinerja Karyawan & & & \\
\hline Butir Pertanyaan 1 & 0,874 & $0,000<0,05$ & Valid \\
\hline Butir Pertanyaan 2 & 0,823 & $0,000<0,05$ & Valid \\
\hline Butir Pertanyaan 3 & 0,852 & $0,000<0,05$ & Valid \\
\hline Butir Pertanyaan 4 & 0,697 & $0,000<0,05$ & Valid \\
\hline
\end{tabular}

Sumber : Data Primer Diolah (2015)

Hasil uji validitas menunjukkan bahwa nilai korelasi antara jawaban responden di setiap butir pertanyaan dengan nilai total jawaban responden menghasilkan nilai signifikan yaitu $<\alpha=0,05$ sehingga untuk variabel motivasi, budaya organisasi, kepuasan kerja dan kinerja karyawan diukur dengan 4 item pertanyaan.

Hasil Uji Reliabilitas

\begin{tabular}{|l|c|c|}
\hline \multicolumn{1}{|c|}{ Variabel } & $\begin{array}{c}\text { Cronbach's } \\
\text { Alpha }\end{array}$ & Keterangan \\
\hline Motivasi & $0,873>0,70$ & Reliabel \\
\hline Budaya Organisasi & $0,787>0,70$ & Reliabel \\
\hline Kepuasan Kerja & $0,802>0,70$ & Reliabel \\
\hline Kinerja Karyawan & $0,826>0,70$ & Reliabel \\
\hline
\end{tabular}

Sumber : Data Primer Diolah (2015) 
Nilai cronbach's alpha variabel motivasi, budaya organisasi, kepuasan kerja dan kinerja karyawan lebih besar dari 0,70 sehingga indikator atau kuesioner dari keempat variabel dinyatakan handal atau reliabel sebagai alat ukur variabel.

\section{Uji Kelayakan Model :}

Koefisien Determinasi

Motivasi dan Budaya Organisasi Terhadap Kepuasan Kerja

Model Summary

\begin{tabular}{|l|r|r|r|r|}
\hline Model & \multicolumn{1}{|c|}{$\mathrm{R}$} & $\mathrm{R}$ Square & $\begin{array}{c}\text { Adjusted } \\
\text { R Square }\end{array}$ & $\begin{array}{r}\text { Std. Error of } \\
\text { the Estimate }\end{array}$ \\
\hline 1 &, $921^{\mathrm{a}}$ &, 848 &, 845 & 1,193 \\
\hline
\end{tabular}

a. Predictors: (Constant), Budaya Organisasi, Motiv asi

Sumber : Data Primer Diolah (2015)

Besarnya koefisien determinasi dapat dilihat pada nilai Adjusted $R$ Square sebesar 0,845 . Hasil ini dapat diartikan motivasi dan budaya organisasi mempengaruhi kepuasan kerja sebesar sebesar 84,5\% (0,845 x 100\%, sementara itu 15,5\% (100\%$84,5 \%)$ kepuasan kerja dipengaruhi oleh faktor selain motivasi dan budaya organisasi. Dengan nilai koefisien determinasi yang mendekati nilai satu berarti model regresi motivasi dan budaya organisasi terhadap kepuasan kerja termasuk fit atau baik.

Koefisien Determinasi

Motivasi, Budaya Organisasi dan Kepuasan Kerja

Terhadap Kinerja Karyawan

Model Summary

\begin{tabular}{|l|r|r|r|r|}
\hline Model & \multicolumn{1}{|c|}{$\mathrm{R}$} & $\mathrm{R}$ Square & $\begin{array}{c}\text { Adjusted } \\
\text { R Square }\end{array}$ & $\begin{array}{r}\text { Std. Error of } \\
\text { the Estimate }\end{array}$ \\
\hline 1 &, $943^{\mathrm{a}}$ &, 890 &, 886 & 1,027 \\
\hline
\end{tabular}

a. Predictors: (Constant), Kepuasan Kerja, Motivasi, Buday a Organisasi

Sumber : Data Primer Diolah (2015)

Besarnya koefisien determinasi dapat dilihat pada nilai Adjusted $R$ Square sebesar 0,886. Hasil ini dapat diartikan motivasi, budaya organisasi dan kepuasan kerja mempengaruhi kinerja karyawan sebesar 88,6\% (0,886 x 100\%, sementara itu 11,4\% (100\%- 88,6\%) kinerja karyawan dipengaruhi oleh faktor selain motivasi, budaya organisasi dan kepuasan kerja. Dengan nilai koefisien determinasi yang 
mendekati nilai satu berarti model regresi motivasi, budaya organisasi dan kepuasan kerja terhadap kinerja karyawan termasuk fit atau baik.

$$
\mathrm{Uji}-\mathrm{F}
$$

Motivasi dan Budaya Organisasi Terhadap Kepuasan Kerja

ANOVA

\begin{tabular}{|c|c|c|c|c|c|c|}
\hline \multicolumn{2}{|c|}{ Model } & $\begin{array}{l}\text { Sum of } \\
\text { Squares }\end{array}$ & $\mathrm{df}$ & Mean Square & $\mathrm{F}$ & Sig. \\
\hline \multirow[t]{3}{*}{$\overline{1}$} & Regression & 660,684 & 2 & 330,342 & 232,218 &, $000^{\mathrm{a}}$ \\
\hline & Residual & 118,072 & 83 & 1,423 & & \\
\hline & Total & 778,756 & 85 & & & \\
\hline
\end{tabular}

a. Predictors: (Constant), Buday a Organisasi, Motivasi

b. Dependent Variable: Kepuasan Kerja

Sumber : Data Primer Diolah (2015)

Hasil uji - F mendapatkan nilai sebesar 232,218 dengan sig.0,000 $<\alpha=0,05$. Dengan hasil ini maka motivasi dan budaya organisasi berpengaruh signifikan terhadap kepuasan kerja secara simultan (bersama-sama), sehingga model regresi yang digunakan dinyatakan fit atau baik.

$$
\mathrm{Uji}-\mathrm{F}
$$

Motivasi, Budaya Organisasi dan Kepuasan Kerja

Terhadap Kinerja Karyawan

\begin{tabular}{|c|c|c|c|c|c|c|}
\hline Model & & $\begin{array}{l}\text { Sum of } \\
\text { Squares }\end{array}$ & $\mathrm{df}$ & Mean Square & $\mathrm{F}$ & Sig. \\
\hline 1 & $\begin{array}{l}\text { Regression } \\
\text { Residual } \\
\text { Total }\end{array}$ & $\begin{array}{r}699,136 \\
86,503 \\
785,640\end{array}$ & $\begin{array}{r}3 \\
82 \\
85\end{array}$ & $\begin{array}{r}233,045 \\
1,055\end{array}$ & 220,914 &, $000^{\mathrm{a}}$ \\
\hline
\end{tabular}

ANOVA

a. Predictors: (Constant), Kepuasan Kerja, Motivasi, Budaya Organisasi

b. Dependent Variable: Kinerja Kary awan

Sumber : Data Primer Diolah (2015)

Hasil uji - F mendapatkan nilai sebesar 220,914 dengan sig.0,000 $<\alpha=0,05$.

Dengan hasil ini maka motivasi, budaya organisasi dan kepuasan kerja berpengaruh signifikan terhadap kinerja karyawan secara simultan (bersama-sama), sehingga model regresi yang digunakan dinyatakan fit atau baik. 


\section{Analisis Jalur (Path Analysis)}

\section{Hasil Regresi}

Motivasi dan Budaya Organisasi Terhadap Kepuasan Kerja

Coefficients

\begin{tabular}{|c|c|c|c|c|c|c|}
\hline \multirow[b]{2}{*}{ Mod } & & \multicolumn{2}{|c|}{$\begin{array}{l}\text { Unstandardized } \\
\text { Coeff icients }\end{array}$} & \multirow{2}{*}{$\begin{array}{c}\text { Standardized } \\
\text { Coeff icients } \\
\text { Beta }\end{array}$} & \multirow[b]{2}{*}{$\mathrm{t}$} & \multirow[b]{2}{*}{ Sig. } \\
\hline & & $\mathrm{B}$ & Std. Error & & & \\
\hline \multirow[t]{3}{*}{$\overline{1}$} & (Constant) & ,773 & ,617 & & 1,253 & ,214 \\
\hline & Motivasi & ,397 & 096 & ,434 & 4,110 & 000 \\
\hline & Buday a Organisasi &, 532 & ,111 &, 507 & 4,805 &, 000 \\
\hline
\end{tabular}

a. Dependent Variable: Kepuasan Kerja

Sumber : Data Primer Diolah (2015)

Nilai koefisien regresi dapat dilihat pada standardized coefficients dan berdasarkan dari nilai koefisien tersebut dapat dibuat persamaan sebagai berikut :

$$
\mathrm{Y}_{1}=0,434 \mathrm{X}_{1}+0,507 \mathrm{X}_{2}
$$

Persamaan regresi tersebut dapat dartikan sebagai berikut :

a. Koefisien regresi motivasi $\left(b_{1}\right)$ positif sebesar 0,434 . Hal ini berarti setiap ada peningkatan motivasi akan meningkatkan kepuasan kerja karyawan.

b. Koefisien regresi budaya organisasi $\left(b_{2}\right)$ positif sebesar 0,507 . Hal ini berarti setiap ada pelaksanaan budaya organisasi yang lebih baik maka akan meningkatkan kepuasan kerja karyawan.

\section{Hasil Regresi}

Motivasi, Budaya Organisasi dan Kepuasan Kerja

Terhadap Kinerja Karyawan

Coefficients ${ }^{\mathrm{a}}$

\begin{tabular}{|ll|r|r|r|r|r|}
\hline & & \multicolumn{2}{|c|}{$\begin{array}{c}\text { Unstandardized } \\
\text { Coeff icients }\end{array}$} & \multicolumn{2}{c|}{$\begin{array}{c}\text { Standardized } \\
\text { Coefficients }\end{array}$} & \\
\cline { 3 - 5 } Model & \multicolumn{1}{|c|}{ B } & Std. Error & \multicolumn{1}{c|}{ Beta } & \multicolumn{1}{c|}{ Sig. } \\
\hline 1 & (Constant) &, 094 &, 536 & &, 175 &, 861 \\
& Motivasi &, 192 &, 091 &, 209 & 2,103 &, 039 \\
& Buday a Organisasi &, 264 &, 108 &, 250 & 2,445 &, 017 \\
& Kepuasan Kerja &, 516 &, 095 &, 513 & 5,454 &, 000 \\
\hline
\end{tabular}

a. Dependent Variable: Kinerja Karyawan

Sumber : Data Primer Diolah (2015)

Nilai koefesien regresi dapat dilihat pada standardized coefficients dan berdasarkan dari nilai koefisien tersebut dapat dibuat persamaan sebagai berikut : $\mathrm{Y}_{2}=0,209 \mathrm{X}_{1}+0,250 \mathrm{X}_{2}+0,513 \mathrm{Y}_{1}$

Persamaan regresi tersebut dapat dartikan sebagai berikut : 
a. Koefisien regresi motivasi $\left(b_{1}\right)$ positif sebesar 0,209 . Hal ini berarti setiap ada peningkatan motivasi akan meningkatkan kinerja karyawan.

b. Koefisien regresi budaya organisasi $\left(b_{2}\right)$ positif sebesar 0,250 . Hal ini berarti setiap ada ada pelaksanaan budaya organisasi yang lebih baik akan meningkatkan kinerja karyawan.

c. Koefisien regresi kepuasan kerja $\left(b_{3}\right)$ positif sebesar 0,513. Hal ini berarti setiap ada peningkatan kepuasan kerja akan meningkatkan kinerja karyawan.

\section{Pengujian Hipotesis $(\mathbf{U j i}-\mathbf{t})$}

Hasil Uji - $\mathrm{t}$

Motivasi dan Budaya Organisasi Terhadap Kepuasan Kerja

Coefficients ${ }^{\mathrm{a}}$

\begin{tabular}{|c|c|c|c|c|c|c|}
\hline \multirow{2}{*}{\multicolumn{2}{|c|}{ Model }} & \multicolumn{2}{|c|}{$\begin{array}{c}\text { Unstandardized } \\
\text { Coeff icients }\end{array}$} & \multirow{2}{*}{$\begin{array}{c}\text { Standardized } \\
\text { Coeff icients } \\
\text { Beta }\end{array}$} & \multirow[b]{2}{*}{$\mathrm{t}$} & \multirow[b]{2}{*}{ Sig. } \\
\hline & & $\mathrm{B}$ & Std. Error & & & \\
\hline & (Constant) & ,773 & ,617 & & 1,253 & ,214 \\
\hline & Motivasi & ,397 & ,096 & ,434 & 4,110 & ,000 \\
\hline & Buday a Organisasi &, 532 & ,111 & ,507 & 4,805 &, 000 \\
\hline
\end{tabular}

a. Dependent Variable: Kepuasan Kerja

Sumber : Data Primer Diolah (2015)

Berdasarkan dari hasil uji - $\mathrm{t}$ maka dapat dilakukan pengujian hipotesis sebagai berikut :

1. Hasil uji - t motivasi terhadap kepuasan kerja sebesar 4,110 dengan sig. $0,000<\alpha=0,05$. Hal ini berarti menerima hipotesis $\left(\mathrm{Ha}_{1}\right)$ yang menyatakan motivasi berpengaruh terhadap kepuasan kerja.

2. Hasil uji - $\mathrm{t}$ budaya organisasi terhadap kepuasan kerja sebesar 4,805 dengan sig. $0,000<\alpha=0,05$. Hal ini berarti menerima hipotesis $\left(\mathrm{Ha}_{2}\right)$ yang menyatakan budaya organisasi berpengaruh terhadap kepuasan kerja. 
Hasil Uji - $\mathrm{t}$

Motivasi, Budaya Organisasi dan Kepuasan Kerja

Terhadap Kinerja Karyawan

Coefficients ${ }^{\mathrm{a}}$

\begin{tabular}{|ll|r|r|r|r|r|}
\hline \multirow{2}{*}{ Model } & \multicolumn{2}{|c|}{$\begin{array}{c}\text { Unstandardized } \\
\text { Coeff icients }\end{array}$} & \multicolumn{2}{c|}{$\begin{array}{c}\text { Standardized } \\
\text { Coeff icients }\end{array}$} & \\
\cline { 3 - 5 } & & \multicolumn{1}{|c|}{ B } & Std. Error & \multicolumn{1}{c|}{ Beta } & \multicolumn{1}{c|}{ Sig. } \\
\hline 1 & (Constant) &, 094 &, 536 & &, 175 &, 861 \\
& Motivasi &, 192 &, 091 &, 209 & 2,103 &, 039 \\
& Buday a Organisasi &, 264 &, 108 &, 250 & 2,445 &, 017 \\
& Kepuasan Kerja &, 516 &, 095 &, 513 & 5,454 &, 000 \\
\hline
\end{tabular}

a. Dependent Variable: Kinerja Kary awan

Sumber : Data Primer Diolah (2015)

3. Hasil uji $-\mathrm{t}$ kepuasan kerja terhadap kinerja karyawan sebesar 5,454 dengan sig. $0,000<\alpha=0,05$. Hal ini berarti menerima hipotesis $\left(\mathrm{Ha}_{3}\right)$ yang menyatakan kepuasan kerja berpengaruh terhadap kinerja karyawan.

4. Hasil uji - t motivasi terhadap kinerja karyawan sebesar 2,103 dengan sig. $0,039<\alpha=0,05$. Hal ini berarti menerima hipotesis $\left(\mathrm{Ha}_{4}\right)$ yang menyatakan motivasi berpengaruh terhadap kinerja karyawan.

5. Hasil uji - $\mathrm{t}$ budaya organisasi terhadap kinerja karyawan sebesar 2,445 dengan sig. $0,017<\alpha=0,05$. Hal ini berarti menerima hipotesis $\left(\mathrm{Ha}_{4}\right)$ yang menyatakan budaya organisasi berpengaruh terhadap kinerja karyawan.

\section{Pengujian Variabel Intervening (Pengaruh Langsung dan Tidak Langsung)}

Uji analisis jalur digunakan untuk membuktikan apakah variabel kepuasan kerja menjadi variabel yang memediasi antara motivasi dan budaya organisasi. terhadap kinerja karyawan. Analisis dilakukan berdasarkan dari nilai standardized coefficients dari hasil regresi dan dapat dibuat analisis jalur sebagai berikut : 


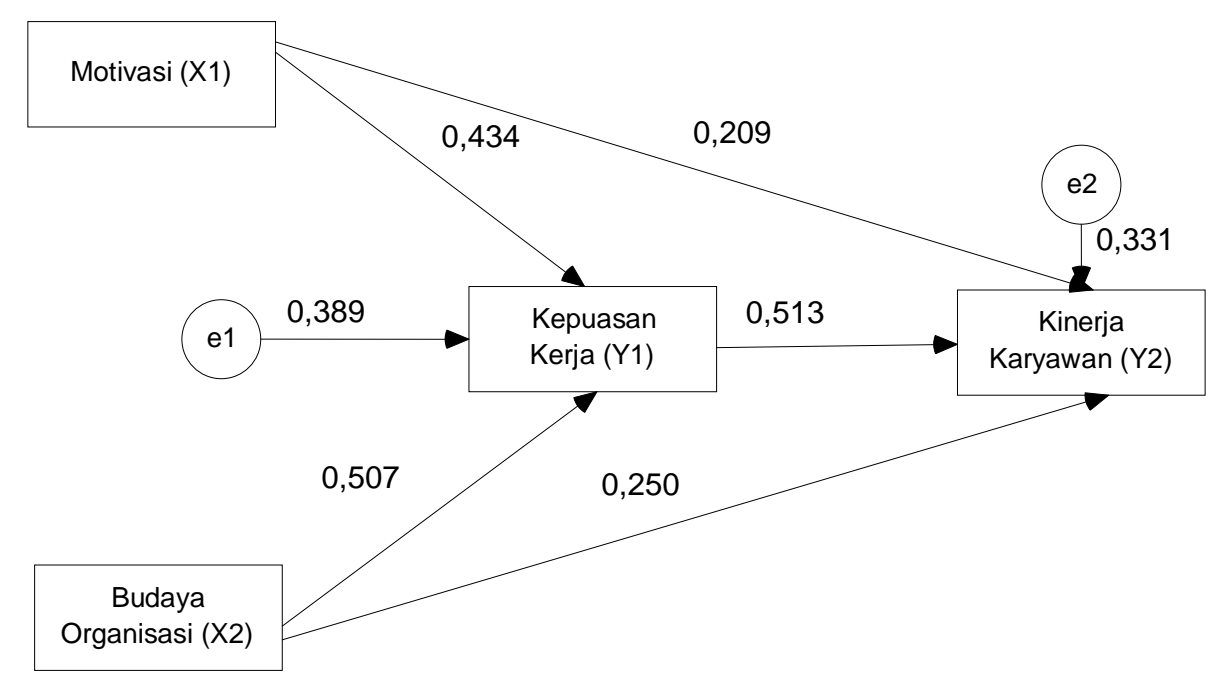

Gambar 2

Analisis Jalur Motivasi dan Budaya Organisasi Terhadap Kinerja Karyawan Melalui Kepuasan Kerja

Berdasarkan dari gambar analisis jalur maka dapat dianalisa sebagai berikut :

1. Analisis Jalur Motivasi Terhadap Kinerja Karyawan Melalui Kepuasan Kerja

a. Pengaruh langsung motivasi terhadap kinerja karyawan sebesar 0,209.

b. Pengaruh motivasi terhadap kepuasan kerja sebesar 0,434 dan pengaruh kepuasan kerja terhadap kinerja karyawan sebesar 0,513, dengan demikian pengaruh tidak langsung motivasi terhadap kinerja karyawan melalui kepuasan kerja adalah sebesar $0,434 \times 0,513=0,223$

Hasil perhitungan menunjukkan pengaruh tidak langsung motivasi terhadap kinerja karyawan melalui kepuasan kerja lebih besar dibanding pengaruh langsung motivasi terhadap kinerja karyawan, sehingga dapat disimpulkan kepuasan kerja mampu menjadi variabel yang memediasi antara motivasi terhadap kinerja karyawan.

2. Analisis Jalur Budaya Organisasi Terhadap Kinerja Karyawan Melalui Kepuasan Kerja

a. Pengaruh langsung budaya organisasi terhadap kinerja karyawan sebesar 0,250 .

b. Pengaruh budaya organisasi terhadap kepuasan kerja sebesar 0,507 dan pengaruh kepuasan kerja terhadap kinerja karyawan sebesar 0,513, dengan 
demikian pengaruh tidak langsung budaya organisasi terhadap kinerja karyawan melalui kepuasan kerja adalah sebesar $0,507 \times 0,513=0,260$.

Hasil perhitungan menunjukkan pengaruh tidak langsung budaya organisasi terhadap kinerja karyawan melalui kepuasan kerja lebih besar dibanding pengaruh langsung budaya organisasi terhadap kinerja karyawan, sehingga dapat disimpulkan kepuasan kerja mampu menjadi variabel yang memediasi antara budaya organisasi terhadap kinerja karyawan.

\section{KESIMPULAN}

Kesimpulan penelitian mengenai Pengaruh Motivasi dan Budaya Organisasi Terhadap Kepuasan Kerja serta Implikasinya Terhadap Kinerja Karyawan Pada RSU Salatiga, adalah sebagai berikut :

1. Hasil uji hipotesis membuktikan bahwa motivasi berpengaruh terhadap kepuasan kerja, dengan didapat hasil uji $-\mathrm{t}$ sebesar 4,110 dan sig. $0,000<\alpha=0,05$. Berdasarkan dari hasil yang didapat ini dapat ditarik kesimpulan bahwa adanya peningkatan pada motivasi yang ditunjukkan karyawan maka akan semakin meningkatkan kepuasan kerja karyawan RSU Salatiga.

2. Hasil uji hipotesis membuktikan bahwa budaya organisasi berpengaruh terhadap kepuasan kerja, dengan didapat hasil uji - t sebesar 4,805 dan sig.0,000 $<\alpha=0,05$. Berdasarkan dari hasil yang didapat ini dapat ditarik kesimpulan bahwa adanya pelaksanaan budaya organisasi yang lebih baik, maka akan semakin meningkatkan kepuasan kerja karyawan RSU Salatiga.

3. Hasil uji hipotesis membuktikan bahwa kepuasan kerja berpengaruh terhadap kinerja karyawan, dengan didapat hasil uji $-\mathrm{t}$ sebesar 5,454 dan sig. 0,000 $<\alpha=$ 0,05. Berdasarkan dari hasil yang didapat ini dapat ditarik kesimpulan bahwa adanya peningkatan kepuasan kerja yang dirasakan oleh karyawan, maka akan semakin meningkatkan kinerja karyawan RSU Salatiga.

4. Hasil uji hipotesis membuktikan bahwa motivasi berpengaruh terhadap kinerja karyawan, dengan didapat hasil uji $-\mathrm{t}$ sebesar 2,103 dan sig. 0,039 $<\alpha=0,05$. Berdasarkan dari hasil yang didapat ini dapat ditarik kesimpulan bahwa adanya peningkatan pada motivasi yang ditunjukkan karyawan maka akan semakin meningkatkan kinerja karyawan RSU Salatiga. 
5. Hasil uji hipotesis membuktikan bahwa budaya organisasi berpengaruh terhadap kinerja karyawan, dengan didapat hasil uji - t sebesar 2,445 dan sig. 0,017< $<=$ 0,05. Berdasarkan dari hasil yang didapat ini dapat ditarik kesimpulan bahwa adanya pelaksanaan budaya organisasi yang lebih baik, maka akan semakin meningkatkan kinerja karyawan RSU Salatiga.

6. Hasil analisis jalur memperlihatkan bahwa pengaruh tidak langsung motivasi terhadap kinerja karyawan melalui kepuasan kerja lebih besar dibanding pengaruh langsung motivasi terhadap kinerja karyawan. Dengan hasil ini maka dapat disimpulkan kepuasan kerja menjadi variabel yang memediasi antara motivasi terhadap kinerja karyawan atau adanya motivasi dalam bekerja akan menumbuhkan rasa puas dalam bekerja dan rasa puas yang dirasakan ini akan berpengaruh terhadap terciptanya kinerja yang baik dari para karyawan.

7. Hasil analisis jalur memperlihatkan bahwa pengaruh tidak langsung budaya organisasi terhadap kinerja karyawan melalui kepuasan kerja lebih besar dibanding pengaruh langsung budaya organisasi terhadap kinerja karyawan. Dengan hasil ini maka dapat disimpulkan kepuasan kerja menjadi variabel yang memediasi antara budaya organisasi terhadap kinerja karyawan atau adanya pelaksanaan budaya organisasi yang baik akan menumbuhkan rasa puas para karyawan ketika bekerja didalam perusahaan dan rasa puas yang dirasakan ini akan menciptakan kinerja yang baik dari para karyawan.

\section{SARAN}

Saran yang bisa disampaikan berdasarkan dari hasil penelitian yang didapat, adalah sebagai berikut :

1. Secara umum motivasi yang ditunjukkan para karyawan sudah relatif baik. Meskipun demikian untuk lebih mempertahankan dan meningkatkan motivasi para karyawan maka perlu untuk lebih ditingkatkan dari segi pekerjaan yang menarik dan menantang, seperti para karyawan yang dinilai sudah lama menjalankan suatu tugas maka perlu untuk diberikan tugas baru yang belum pernah dijalankan sebelumnya sehingga dapat memberi unsur tantangan didalam bekerja, tetapi dengan tetap mempertimbangkan kompetensi karyawan seperti tingkat pendidikan, 
keahlian dan ketrampilan agar karyawan tertarik untuk menjalankan tugas baru tersebut.

2. Budaya organisasi yang dijalankan memang masih perlu ada evaluasi dalam pelaksanaannya karena dari indikator budaya organisasi belum semuanya mendapatkan penilaian yang baik dari para karyawan, seperti karyawan tidak mengeluh menghadapi situasi yang tidak biasa (salah satunya pergantian pimpinan) yang mendapatkan penilaian cukup dari para karyawan. Hal ini perlu disikapi dengan mempertimbangkan masukan dan saran dari para karyawan serta melihat kepribadian calon pimpinan pada saat melakukan penentuan pimpinan baru didalam suatu divisi kerja. Tindakan ini perlu dilakukan guna menentukan pimpinan yang tepat untuk memimpin suatu divisi yaitu pimpinan yang memang memiliki kemampuan mendukung dan dapat diterima oleh para bawahannya sehingga dapat menciptakan jalinan kerjasama yang baik antara pimpinan dan bawahan agar nantinya kinerja yang dihasilkan masing-masing pihak bisa lebih baik.

3. Kepuasan kerja yang dirasakan karyawan memang masih perlu ada peningkatan karena dari indikator dari kepuasan kerja belum semuanya mendapatkan penilaian yang baik dari para karyawan seperti dengan rekan kerja sudah terjalin hubungan harmonis yang mendapatkan penilaian cukup dari para karyawan. Hal ini perlu disikapi dengan lebih memperat jalinan komunikasi yang penuh kekeluargaan di antara karyawan yaitu dengan membentuk suatu perkumpulan atau forum sebagai tempat untuk saling bertemu, kemudian menjadi tempat mediasi untuk menyelesaikan suatu permasalahan atau konflik yang terjadi di antara karyawan dan juga menggelar berbagai kegiatan yang dapat memperat hubungan diantara para karyawan. Hubungan yang lebih erat dan harmonis akan berpengaruh pada jalinan kerjasama yang baik dalam bekerja sehingga dapat menghasilkan kinerja yang baik dari masing-masing karyawan. 


\section{DAFTAR PUSTAKA}

Anoraga, Pandji. 2006. Psikologi Kerja. Cetakan Keempat. PT Rineka Cipta. Jakarta.

Arikunto, Suharsimi. 2006. Prosedur Penelitian : Suatu Pendekatan Praktek. PT. Rineka Cipta. Jakarta.

Brahmasari, Ida Ayu dan Agus Suprayetno. 2008. "Pengaruh Motivasi Kerja, Kepemimpinan dan Budaya Organisasi Terhadap Kepuasan Kerja dan Budaya Organisasi Terhadap Kepuasan Kerja Karyawan serta Dampaknya pada Kinerja Perusahaan (Studi kasus pada PT. Pei Hai International Wiratama Indonesia)". Jurnal Manajemen dan Kewirausahaan. Vol. 10. No. 2. September 2008. Hal. 124 - 135. Universitas 17 Agustus. Surabaya.

Ghozali, Imam. 2009. Aplikasi Analisis Multivariate Dengan Program SPSS. Cetakan Keempat. Badan Penerbit Universitas Diponegoro. Semarang.

Guritno, Bambang dan Waridin. 2005. "Pengaruh Persepsi Karyawan Mengenai Perilaku Kepemimpinan, Kepuasan Kerja dan Motivasi terhadap Kinerja". Jurnal Riset dan Bisnis Indonesia. Vol. 1. No. 1 Januari. Hal. 63 - 74. Unissula. Semarang.

Hakim, Abdul. 2006. "Analisis Pengaruh Motivasi, Komitmen Organisasi Dan Iklim Organisasi Terhadap Kinerja Pegawai Pada Dinas Perhubungan Dan Telekomunikasi Propinvsi Jawa Tengah”. Jurnal Riset Dan Bisnis Indonesia (JRBI). Vol. 2. No. 2. Juli. Hal. 165 - 180. Unnisula. Semarang.

Hasibuan, Malayu. 2007. Manajemen Sumber Daya Manusia. Edisi Revisi. Cetakan Kesepuluh. Bumi Aksara. Jakarta.

Istijanto. 2005. Sumber Daya Manusia. Cara Praktis Mendekteksi Dimensi-Dimensi Kinerja Karyawan. PT. Gramedia Pustaka Utama. Jakarta.

Jogiyanto. 2004. Metode Penelitian Bisnis : Salah Kaprah dan PengalamanPengalaman. Edisi 2004/2005. BPFE. Yogyakarta.

Kreitner, Robert dan Angelo Kinicki. 2005. Perilaku Organisasi : Organizational Behavior. Buku Kesatu. Edisi Kelima. Salemba Empat. Jakarta.

Lok, Peter and John Craword. 2004. "The effect of organizational culture and leadership style on job satisfaction and organisational commitment". Journal of Management Development. Vol. 23 No. 4. 2004, pp. 321-338. School of Management, University of Technology, Sydney, Australia.

Mangkunegara, Anwar Prabu. 2009. Manajemen Sumber Daya Manusia. Cetakan Kesembilan. PT. Remaja Rosdakarya. Bandung. 
Mangkuprawira, Sjafri dan Aida Vitayala Hubeis. 2007. Manajemen Mutu Sumber Daya Manusia. Cetakan Pertama. Bogor. Ghalia Indonesia.

Masrukhin dan Waridin. 2006. "Pengaruh Motivasi, Kepuasan Kerja, Budaya Organisasi dan Kepemimpinan Terhadap Kinerja Pegawai”. Jurnal Riset dan Bisnis Indonesia. Hal. 196 - 209. Unissula. Semarang.

Mas'ud, Fuad. 2004. Survai Diagnosis Organisasional : Konsep dan Aplikasi. Badan Peneribit UNDIP. Semarang.

Oluseyi, Shadare A. and T. Ayo Hammed. 2009. "Influence of Work Motivation, Leadership Effectiveness and Time Management on Employees' Performance in Some Selected Industries in Ibadan, Oyo State, Nigeria”. European Journal of Economics, Finance and Administrative Sciences. pp. 7 - 17. Department of Industrial Relations and Personnel Management University of Lagos, Lagos Nigeria.

Panggabean, Mutiara S. 2004. Manajemen Sumber Daya Manusia. Cetakan Kedua. Ghalia Indonesia. Jakarta.

Riduwan dan Engkos Achmad Kuncoro. 2008. Cara Menggunakan Dan Memakai Analisis Jalur (Path Analysis)”. Cetakan Kedua. Alfabeta. Bandung.

Rivai, Veithzal. 2004. Manajemen Sumber Daya Manusia untuk Perusahaan : Dari Teori ke Praktik. PT Raja Grafindo Persada. Jakarta.

Robbins, Stephen P. 2006. Perilaku Organisasi. Edisi Kesepuluh. PT. Indeks. Jakarta.

Samsudin, Sadili.2006. Manajemen Sumber Daya Manusia. Cetakan Kesatu. Pustaka Setia. Bandung.

Setiyawan, Purnomo Budhi dan Waridin. 2006. "Pengaruh Disiplin Kerja Karyawan dan Budaya Organisasi terhadap Kinerja Di Divisi Radiologi RSUP Dokter Kariadi Semarang”. Jurnal Riset Bisnis Indonesia. Vol. 2. No. 2. Juli. Hal. 181 - 198. Unissula. Semarang.

Simamora, Henry. 2004. Manajemen Sumber Daya Manusia. Cetakan Pertama. STIE YKPN. Yogyakarta.

Slamet, Achmad. 2007. Manajemen Sumber Daya Manusia. Universitas Negeri Semarang Press. Semarang.

Sugiyono. 2005. Metode Penelitian Bisnis. Cetakan Kedelapan. CV Alfabeta. Bandung.

Suharto dan Budi Cahyono. 2005. "Pengaruh Budaya Organisasi, Kepemimpinan dan Motivasi Kerja Terhadap Kinerja Sumber Daya Manusia". Jurnal Riset dan Bisnis Indonesia. Vol. 1. No. 1 Januari. Hal. 13 - 30. Unissula. Semarang.

Pengaruh Motivasi Dan Budaya Organisasi Terhadap Kepuasan Kerja Serta Implikasinya 
Sutrisno, Edy. 2010. Manajemen Sumber Daya Manusia. Edisi Pertama. Cetakan Kedua. Kencana Prenada Media Group. Jakarta.

Tampubolon, Manahan. 2004. Perilaku Keorganisasian (Organization Behavior). Cetakan Pertama. Ghalia Indonesia. Jakarta.

Umar, Husein. 2005. Metode Penelitian : Untuk Skripsi dan Tesis Bisnis. Edisi Baru Cetakan Ketujuh. PT Raja Grafindo Persada. Jakarta.

Usman, Husaini dan Purnomo Setiadi Akbar. 2006. Pengantar Statistika. Edisi Kedua. Cetakan Pertama. PT. Bumi Aksara. Jakarta.

Voon, M.L., M.C. Lo, K.S. Ngui and N.B. Ayob. 2011. "The influence of leadership styles on employees' job satisfaction in public sector organizations in Malaysia". International Journal of Business, Management and Social Sciences. Vol. 2, No. 1, 2011, pp. 24-32. University of Technology Sarawak. Malaysia. 